\title{
SABINE KALKE \\ WHO KNOWS BETTER \\ WHAT THE CITY SHOULD BE?
}

LOCAL GOVERNMENT REFORM IN NORTHERN IRELAND IN 2015

Sabine Kalke, Project Sponsor, Property \& Projects, Belfast City Council ${ }^{1}$; Belfast City Council, The Cecil Ward Building 4-10, Linenhall Street, BELFAST BT2 8BP, Northern Ireland, United Kingdom; tel.: +44 (0) 2890270690 ext: 3515.

E-mail:kalkes@belfastcity.gov.uk

Interviewed by Marina Sapunova²

Abstract

The Local Government Reform in Northern Ireland in 2015 returned decision-making powers on territorial development to the local level. Sabine Kalke, who worked in the department before and after the reform, spoke in her interview about the changes they faced and what additional powers were transferred to local government. The changes mostly affected interactions with stakeholders and the actual development strategy of Belfast. Today, the city determines the priorities and development goals at the local level, and negotiations with major developers are based on these goals. As a result, the interaction has become more meaningful and mutually beneficial.

The reform provides the City Council with a certain flexibility in decision-making: its position remains strong, but with the ability to adjust the plans. After all, the urban development process benefits both the private and the public sector. In this sense, the readiness of each of the parties to an open dialogue becomes key.

The experience of Belfast is becoming particularly important regarding changes in the Russian local government system, which has lost much authority in recent years.

Key words: Northern Ireland; local government; planning department; urban; development;

Belfast; reform; city council; decision making

Citation: Kalke S. (2018) Who Knows Better What the City Should Be? Local Government Reform in Northern Ireland in 2015. Urban Studies and Practices, vol. 3, no 1, pp. 78-87. DOI: https://doi.org/10.17323/usp31201878-87

\section{Q1: How long has the department of urban planning been in Belfast and how were decisions on urban development made before?}

\footnotetext{
A : It is more complicated because it is not only the Planning Department, who is making decisions on urban planning but it is a split responsibility.

11 The Planning Department was created 3 years ago following the local government reform in April 2015, where the bulk of planning functions have been devolved to the 11 councils in Northern Ireland which, through their elected representatives, are responsible and accountable for most planning decisions.
}

1 www.belfastcity.gov.uk

2 Marina Sapunova, urban planner, Vysokovsky Graduate School of Urbanism, Faculty of Urban and Regional Development HSE; 13 bldg. 4 Myasnitskaya Street, Moscow, 101000, Russian Federation. E-mail: msapunova@ hse.ru 
The transfer of most planning functions to the district councils did not just involve the redistribution of functions but included the creation of a new planning system for Northern Ireland. ${ }^{3}$ Before that, the planning function was with the regional Department of Environment (DoE). After the Local Government Reform the number of Northern Ireland government departments has been reduced from 12 to nine. The functions and services delivered by the 12 former departments have been restructured and transferred to the relevant new departments.

The Belfast Planning Service is responsible for delivering planning functions in Belfast. This involves:

- receiving and making decisions on the majority of planning applications;

- enforcing breaches of planning permission;

- making tree preservation orders;

- protecting and preserving built heritage; future.

- producing a local development plan outlining how land should be used and developed in the

Under Local Government Reform, the previous 26 local councils merged to become 11. The map (Fig. 1) shows how the council boundaries have changed.

\section{1 new council areas}
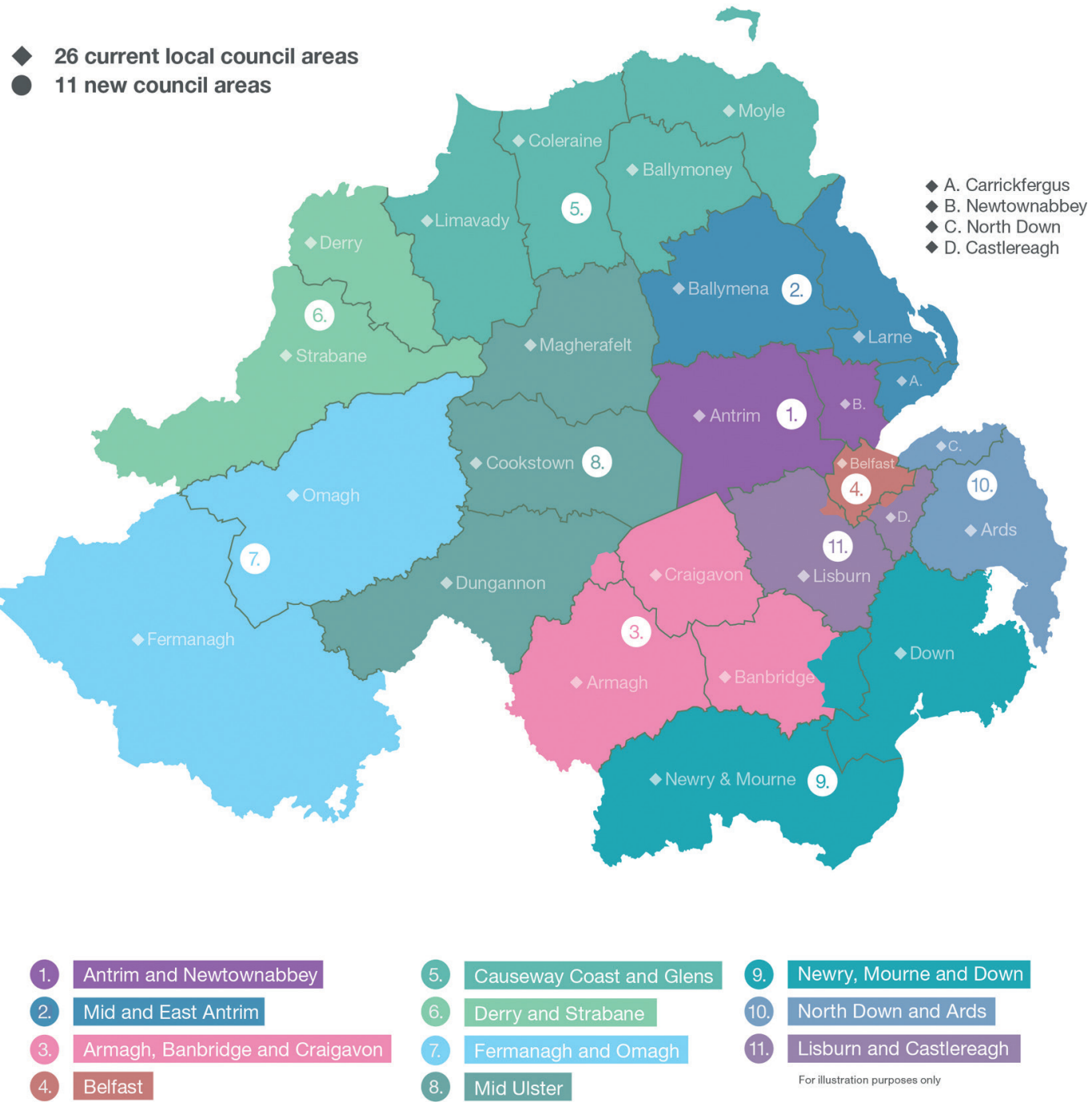

Fig. 1. Under Local Government Reform (LGR)

3 https://www.planningni.gov.uk/index/common-about-doe-planning/about-reform.htm 
Since April 2015 we have been the local planning authority which means all the planning applications are coming to the city, which is normal for most (at least) European cities.

The type, size and complexity of an application will determine how the decision is made. There are three ways in which a decision can be made:

- our Planning Committee considers all major applications, an elected member may request that an application is decided by the Planning Committee, provided they give sound planning reasons for doing so;

- a planning officer has the authority to determine smaller, more straightforward applications;

- the Do E makes decisions that have regional significance.

Below you can see the structure of our organization at the moment (Fig. 2) - it is still under review and will change in the future; some of the departments/units are only temporary.

Structure so far (May 2016)

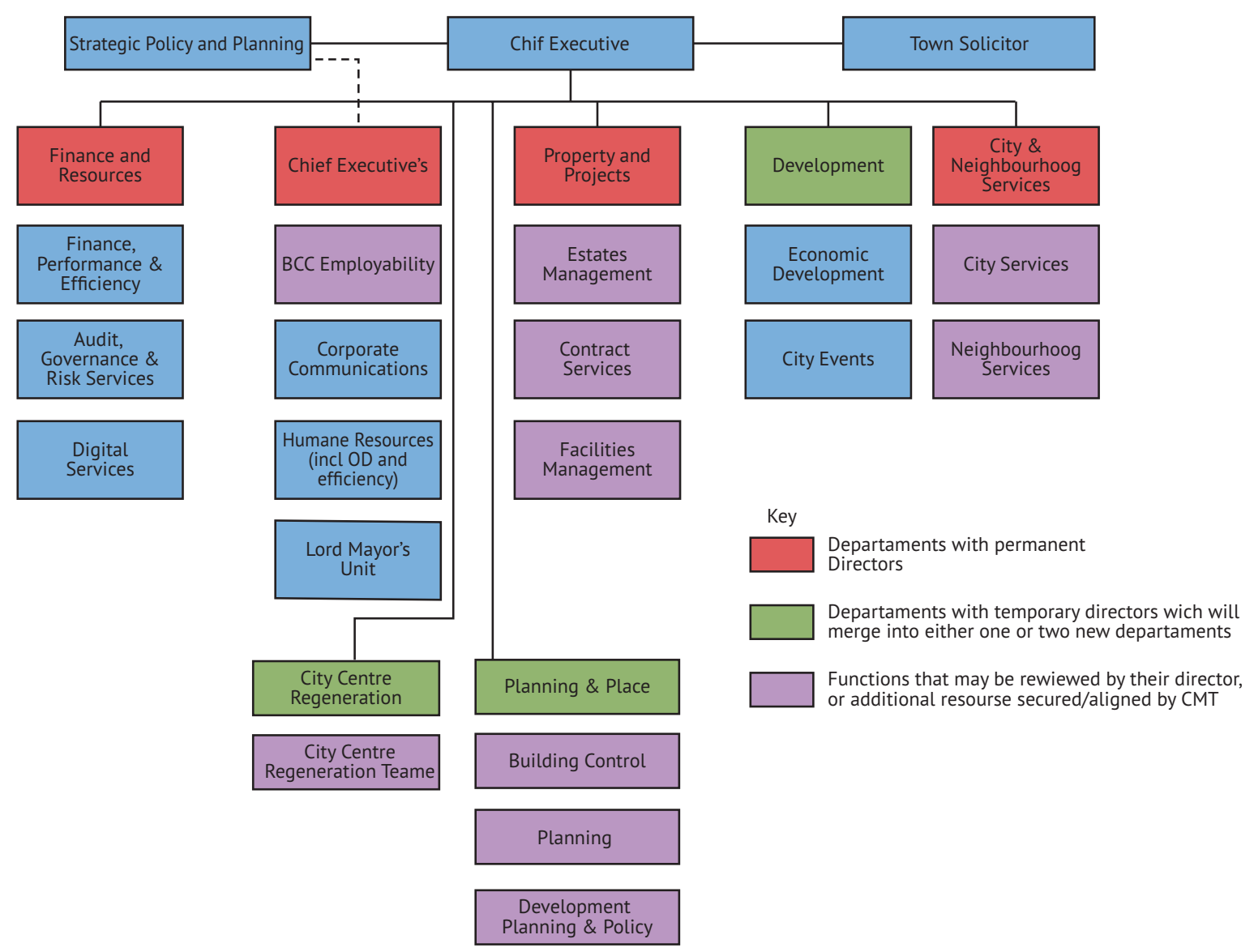

\section{Fig. 2. Structure of Belfast City Council}

With the new planning powers from the DoE, we also took on responsibility for community planning. The Planning Department (Planning \& Place) is responsible for developing a local development plan for Belfast which will set out how we will use and develop land within our council area until 2030.

Work is now underway on this and we will be working with communities and stakeholders in the months ahead to help shape this plan. In Property \& Projects (where I work) we are already involved in many regeneration projects, working in partnership with others to develop local communities and create job and business opportunities.

The projects can be our own assets (such as the Giant's Park), community assets or assets of other organizations and can range in size from a couple of thousand pounds to multi million pound programs. 
Some examples are:

- At 340 acres, Giant's Park is the largest development site in the city. We want to transform this former landfill facility, which we own, into a safe, sustainable asset which attracts investors and creates jobs and other opportunities for our city. This project is part funded by Invest Northern Ireland and the European Regional Development Fund (ERDF), under the European Sustainable Competitiveness Programme for Northern Ireland.

- Belfast's appeal as an international conference destination was boosted significantly through the $£ 29.5$ million expansion of Belfast Waterfront (Fig. 3). We committed $£ 11$ million towards its development, £13.3 million was secured from ERDF and $£ 5.24$ million came from Tourism Northern Ireland.

- Connswater Community Greenway is a $£ 40$ million investment into a new $9 \mathrm{~km}$ linear park along the course of the Loop, Knock and Connswater Rivers in the east of the city. We funded the project along with the Big Lottery Fund, the Department for Communities and the Department for Infrastructure. The project was delivered by us, in partnership with EastSide Partnership.

- Belfast Bikes (Fig. 4) is a public bike share scheme for the city. We delivered this project and the initial capital funding of $£ 230,000$ came from the Department for Regional Development (now Department for Infrastructure).

- The Innovation Factory on Springfield Road is a dynamic, flexible and entrepreneurial hub for start-up businesses and expanding firms specializing in innovation, research and development and other creative solutions. This £9.1 million project was funded by Belfast City Council, Invest Northern Ireland and ERDF under the European Sustainable Competitiveness Program for Northern Ireland.

- The Girdwood Community Hub represented a total investment of $£ 20$ million. Part of our $£ 150$ million Leisure Transformation Program, this state-of-the-art shared space hub offers first-class leisure, community and education facilities in the north of the city.

\section{Q2: What has changed in the Department's management structure after the reform? How is it organized now?}

A: Before the local reform we, as a City Council, only guided certain things, we could not make decisions, we were only consulted. The regional department had to consult with us, but the final decision was at the regional level. We only had control over certain essential services such as bin collection but not the planning service. And now we are the decision makers.

At the administrative level of our department we have a chief executive (our boss), then different departments underneath (see the structure - finance department, strategic policy department, us as a delivery department) who report to the political level. The politicians then also make their de- 


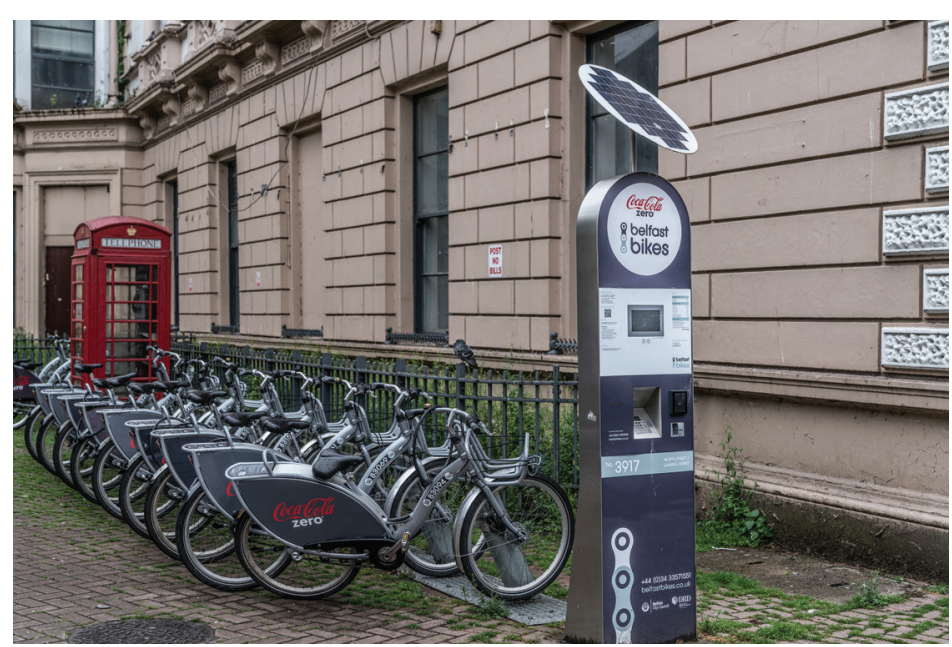

Fig. 4. Belfast Bikes

Source: https://www.flickr.com/photos/infomatique/38515120312/ in/photolist-27bW2UJ-Zmbfbp-DyK1WJ-ZBn2s5-GL1yoc-21GzJRc21Fs4qu-ZnNeoe-24vkZ9Q-DyX9xG-21GzHWM-21DNoFq-21E1bhdZByGUu-GL1zyt-DyX8gU-ZBn3i3-ZmbcsD-ZBmVvA-ZCXCyU/ Attribution-ShareAlike 2.0 Generic (CC BY-SA 2.0) cisions. We give recommendations, and then we have to go to every department that has a corresponding committee, like the one we have to report to, such as a strategic policy and resource committee. They decide on the finance.

The process is organized the following way: when we think that a project is relevant and worth financing, we provide a business case and then go to the committee and show them our arguments for the project. The committee then has to decide if it agrees with us. We are working in a hierarchical system, but we are working in parallel (horizontally) with each other.

Q3: What decisions are you responsible for as a Department? How do you communicate not only with the other departments but with the full range of stakeholders (developers, residents, business, owners, etc.)?

A: At the moment we have developed our strategy, we have developed our plan for Belfast, and this is our vision for the city. It is called The Belfast Agenda, which is a document that outlines what we want to see. ${ }^{4}$

The Belfast Agenda is the city's first community plan, built by a partnership of organizations, led by the Belfast City Council. It represents our joint commitment to the city's long-term success.

Underneath we are now developing smaller plans for different areas, but The Belfast Agenda is the overall vision. Everything that we are doing has to be in line with this. So we always have to justify our plans with the agenda.

We are responsible for developing a Local Development Plan for Belfast, working with local people, to create a clear vision of how the council area should develop and what it will look like in the years to come.

The Local Development Plan will:

- provide a 15-year framework to support the economic and social needs of the city, in line with regional strategies and policies, while delivering sustainable development;

- facilitate growth by coordinating public and private investment to encourage development where it will be of most benefit to the wellbeing of the community;

- allocate sufficient land to meet the needs of the city;

- provide an opportunity for all stakeholders, including the public, to have a say about where and how development within the local area should take place;

- provide a plan-led framework for rational and consistent decision making by the public, private and community sectors and those affected by development proposals;

- deliver the spatial aspects of The Belfast Agenda, the city's community plan.

- Ongoing engagement and community consultation is an important element and these stages are set out in our Statement of Community Involvement.

\section{Q4: Am I right that these documents provide the basic rules of the game for everyone, a single legal framework where all stakeholders work together?}

A: You presented your situation, ${ }^{5}$ where the developer did something not corresponding to the original plan; we hope that this cannot happen in Belfast because we have a strong vision for each area and ground rules. The developer has to bring something that is in line with this master plan. When

\footnotetext{
4 https://yoursay.belfastcity.gov.uk/chief-executives/belfast-agenda/supporting_documents/8535The\%20 Belfast\%20Agenda\%20V20.pdf

5 ZIL Development project.
} 
the developers bring their planning application, they should consult with us to see what we have in mind for this area, and our planning department consults with all the different departments as well. And if their proposal is not in line with our agenda, they have to have good reason to turn this around, to change our plan. There is also consultation with residents, with the community, so that they could provide input as well.

We had a case just now (Markets area) where the developer wanted to create a residential area, there was a significant brownfield site, and he wanted to build offices, a mixed-use development which is close to the city center. It got planning approval because it was ok with our master plan, we envisaged this office area, and there are office and hotels areas nearby. So he got planning approval, but the community appealed against this because they felt that not the functions, but the structure was too tall for the adjacent area (there are individual terraced houses nearby, only 2-storeys high). The developer proposed high rise buildings there, and after the community appealed against this, it stopped.

\section{Q5: How does your strategy compare with other levels: regional and national?}

A: They (the region) have different programs, and we as a city obviously have specific programs, but we also have a lot of programs together. It is more about the regional level, then the national level, because we belong to the UK, so it is a bit difficult. So we have certain money from the UK, but mostly it comes from the regional level, and we mostly work together with the regional level.

They have overarching programs like the Department for Communities for example, which has the Social Investment Fund. This Fund provides financing for deprived communities, and they are responsible for community planning in specific areas. So when we identify projects related to the fund, we can apply for money from them and put it together with our funds, and create programs for different projects.

Again an example of a project I am working on (Lanyon Tunnels).

It is a redevelopment of the railway arches. They are derelict and boarded up, and the community had the idea to re-open the arches and bring social enterprises into those tunnels (small coffee shops, a kindergarten, etc.). Since they cannot do it themselves, they come to us and ask if we can help to deliver this kind of project. We had a look at this and saw that this matches what we want to do in this area, so it is a good thing. We put it on the Belfast investment money fund. Then we presented it to our local politicians to say that this is in line with what we want and we want to work with the community. So they agreed we provided runding for this project.

We knew that we did not have enough money for this project, we went to the regional government, to the Social Investment Fund. We proposed this project saying "we are happy to give $50 \%$ of the money they need, can you bring the other $50 \%$ to the table?" They agreed and then we are funding it together. And there is also a little contribution from the private developers because we are now trying to bring money from the developers when they are approved for big projects. We, as a Council, put conditions for the developers to make a certain contribution to the city. This money then goes to small projects in the area. And in this case, there is a developer who is doing a block nearby, so this was their contribution.

Q6: You mentioned the funds that come from various sources: public, private, or from a consortium of developers and residents. How does it work? What types of projects can be financed from such funds?

A: As a Council, we have different types of programs. The biggest one was launched in 2012 when it was clear that we were getting powers back and everything would change.

I forgot to say when we got planning authority back we also thought, or it was planned that at the same time we would get back the regeneration powers, but we did not. So this still belongs to the Regional Department for Communities, so they are still responsible for all the big regeneration projects even if we work closely together with them.

Because we knew that we would have more responsibilities the Council then decided to create a big investment program (2012) and all the different political parties or politicians chose to support this, in the beginning, it was 150 million pounds for feasible projects. Besides that, we are working together with other regional departments on most projects, and in some cases with private developers. 
At the beginning of any project, we have to do a business plan for it and investigate different funding possibilities. Then we draw funding agreements with various stakeholders, with the other departments or with private investors as well. We outline the governance structure as well: who is responsible for what and where the money is coming from.

Another fund that I probably mentioned briefly in my presentation ${ }^{6}$ was the Local Investment Fund (LIF) which is a small scale investment fund, but communities can apply for it. It is not an open fund, but it is mostly a fund for our local politicians. They work in specific areas, and they have their voters in particular areas, and they agree together with the communities about the projects. For example to refurbish a community hall, or to build something, and then the politicians are coming to us and suggesting different plans for this local investment fund. It is only up to 250,000 pounds, but it works very well because we assess the project if they are feasible and if they are self-managed afterwards.

If they go through the process, they receive the money, and we help them to deliver the project. Sometimes they also get money from private investors for certain projects and then we should again to draw up this funding agreement with the community organizations. Sometimes these organizations invest their own money as well. But we always have to check first if their funding is alright, if their structure is ok, if they own the land or the building or if they have a long-term lease for this. This is called the due diligence process because we have to go through this whole process and check that we are not throwing money at projects that are not worth funding.

\section{Q7: How do you evaluate your work as a Department?}

A: I will describe the procedure we have to evaluate a project and then the approaches we have to assess our work.

Someone comes to us with a project proposal, and we should decide at the very beginning if we will take it further. In our department, we have a physical program that shows all the different project proposals that we receive. And at the moment when some community group comes up with an idea, they come to us and say "we want to develop a community center somewhere, can you help us with delivering this". We consider it an emerging project - just an idea. There is nothing behind this at the moment.

One of us gets the task to have a look at this, to see if it is ok to move it to the next level - if it is in line with our cooperative objectives and The Belfast Agenda - this we call a strategic outline case. So we check very roughly if it is feasible and value for money and all this kind of stuff. And if it conflicts with anything else in the area.

If this is agreed we move it to the next stage, where we look at it more closely, to check what the funding options are and what the details of the case are. This is called an outline business case. And we do economic appraisal as well, which takes time. You cannot do it in two weeks because you have to go into the details to see if it is commercially viable to a certain extent.

The next step is to present it to our committees, and they make the investment decisions: is it worth putting in the money? When the investment decision is made, it means for me I can go ahead with this project, so I can appoint the design team and I go through the whole procurement process.

If everything goes the way we wanted, we have to assess the deliverables of the project. We have just created a structure in this local investment fund to organize this assessment: lessons learned, what we have learned from each other and how we could capture the good and the bad. We do this for all our different programs, so we are responsible for this as well. And we do not leave the project after it is done, we are still responsible for how it works, that everything promised was done, etc. That part is tricky as well.

Q8: I agree that this is a tricky part, so my next question is about public and private interests. How would you explain the idea of the public-private balance in the urban planning process?

A: Yes, in a lot of projects, especially big ones such as a Titanic quarter (Fig. 5 ), ${ }^{7}$ it is usually that the city council has to step in to initiate certain things and get the ball rolling: taking care of the public

6 The presentation Sabine Kalke gave at the International Baikal Winter University Workshop (2018).

7 http://titanic-quarter.com/ 


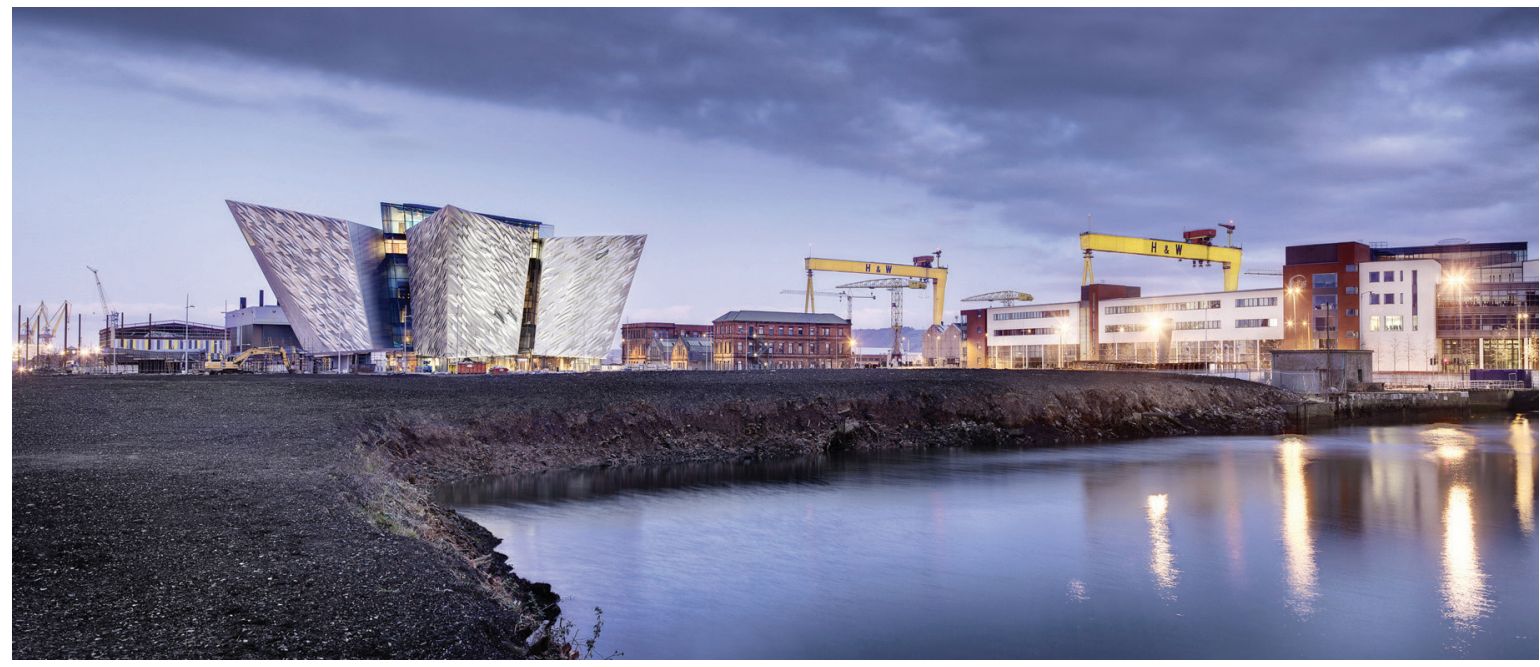

Photo @ William Murphy

\section{a)}

Source: https://www.flickr.com/photos/titanicbelfast/7747739088/in/album-72157630999940602/ Attribution 2.0 Generic (CC BY 2.0)

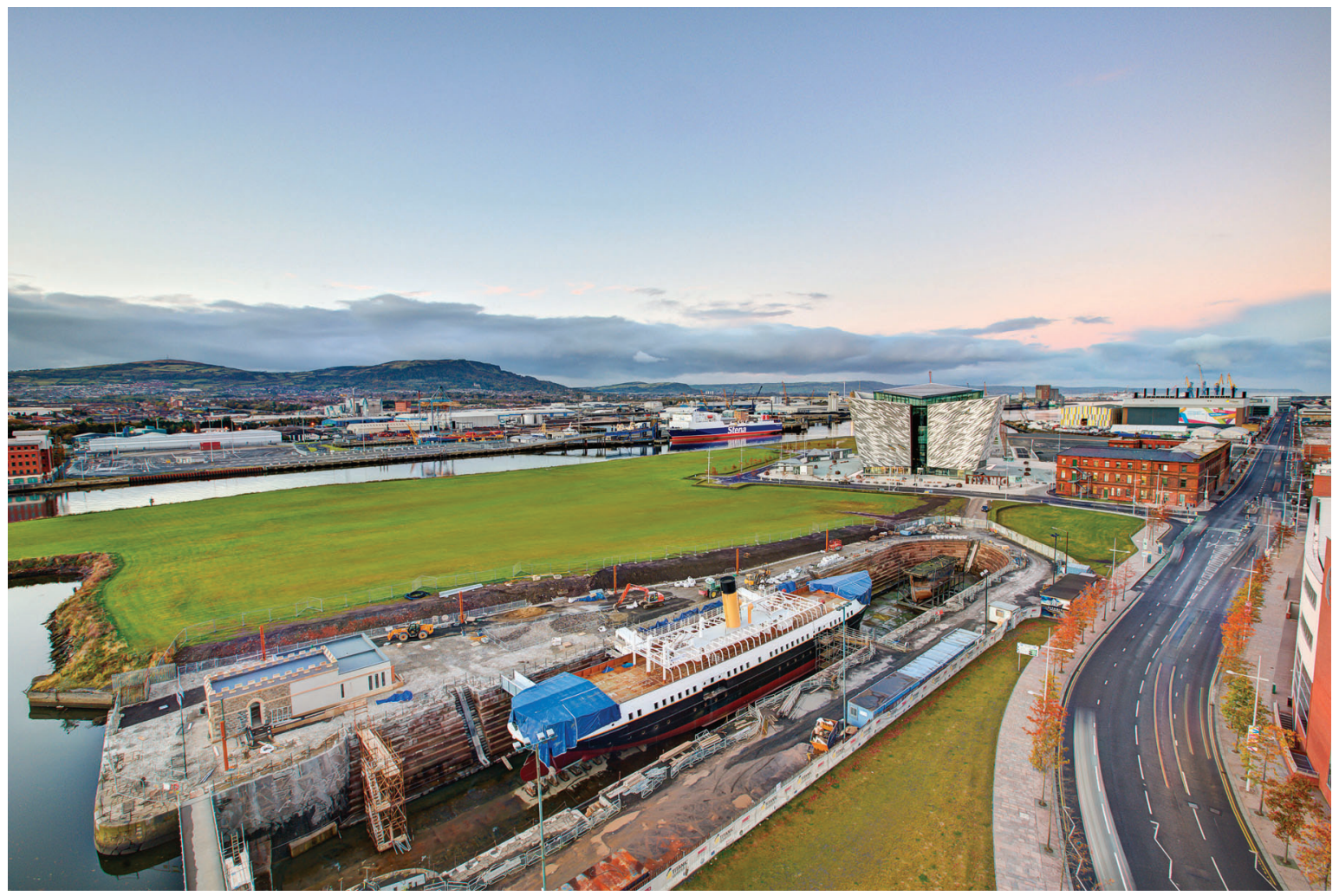

Photo @ William Murphy

b)

Source: https://www.flickr.com/photos/titanicbelfast/8423889070/in/album-72157632628731179/ Attribution 2.0 Generic (CC BY 2.0)

Fig. 5. Titanic Quarter 
interest but inviting the developers as well. We provide a certain level of investment which means that the private investor comes in and multiplies the stakes to a certain extent.

We expect to get a return for every pound we invested so we should prove this. We should show the ways the project will be delivered, to get something back. Then the private investor, or organization, or community takes things on and runs it, to make long-term money on a project.

For example, we are starting now to develop a clean business tech park at the former landfill where the land is ours [Giant's Park]. We got a little bit of funding help from the EU, we prepared the site so that it is ok now for a private developer to come in and build something there.

First, we made sure that all the contamination issues are dealt with, this is the first difficulty with a former landfill site - that everything is capped - and it takes time. But now this is more or less solved, and the location is cleaned up, the infrastructure is in place, the roads are in, all kinds of other infrastructure are in, up to a certain point. So there are prepared plots now that we would like to lease to private developers.

The next step for us is to put out an expression of interest. We say, ok, our plan is only for clean-tech businesses, and if you think you are one of these businesses and you fulfill our guidelines then you can apply for a plot. In other words, people start to approach us according to our expression of interest.

Then we again go through this whole process of due diligence to see if it is a respectable company, if the finance side is ok because we do not want anyone to fail straight away. We check all these things out through a long, long complicated process, so these companies are assessed. After they go through this process and if they still want a plot at the site, they lease a plot of land and become a part of our overall plan.

Afterwards, they can make their small plan application for their plot of land to make small changes in the overall plan.

\section{Q9: And the planning department is always a part of the management team for the site?}

A: Yes, of course. And we are flexible, for example, in this case, it is not easy to find the right companies for this clean-tech concept because it is a complicated site and people are worried about building something on a former landfill. It is not like you have a nice clean site somewhere. It is clean, and it is nice, I think, but obviously, there is a particular risk around this. And clean-tech is not that big in Northern Ireland at the moment, and they are still developing at the moment. So it is not that easy to find the right businesses.

While we were trying to find those businesses, we were approached by the Harbor Commissioners with the idea of building a film studio on this site. They already had a film studio on their site at the Titanic quarter near the harbor. But they also want [this site] because theirs is completely booked for the next I don't know how many years, they are doing so many films at the moment in Northern Ireland. So they thought that this location would be ideal for a film studio.

We had a look at this, we came up with a business case, and they came up with a business case and presented it to us. We checked everything and changed then our plan a little bit. We extend the clean-tech part in the area and left a plot for the development of a film studio.

\section{Q10: So you are flexible to some extent with your plan?}

A: The City Council has to have a certain flexibility. I think you need to be strong as a Council, as the local authority, but you also need to be able to look a little bit beyond your plan. Moreover, if it makes sense, I think you should be able to change your plan. 


\section{САБИН КАЛКЕ}

\section{КТО ЛУЧШЕ ЗНАЕТ, КАКИМ ДОЛЖЕН БЫТЬ ГОРОД? \\ РЕФОРМА МЕСТНОГО САМОУПРАВЛЕНИЯ 2015 Г. В СЕВЕРНОЙ ИРЛАНДИИ}

Сабин Калке, куратор проектов Департамента недвижимости и развития в Городском совете Белфаста; Belfast City Council, The Cecil Ward Building 4-10, Linenhall Street, BELFAST BT2 8BP, Northern Ireland, United Kingdom; tel.: +44 (0) 2890270690 ext: 3515

E-mail: kalkes@belfastcity.gov.uk

\section{Интервьюер: Марина Сапунова}

Проведенная в 2015 г. реформа системы местного самоуправления в Ирландии вернула на местный уровень полномочия принятия решений в отношении территориального развития. Сабин Калке, работавшая в департаменте до и после реформы, рассказывает в интервью об изменениях, связанных с этой реформой. В частности, с какими сложностями она была сопряжена и какие дополнительные полномочия были переданы на местный уровень власти. Изменения коснулись и системы выстраивания взаимодействия

со стейкхолдерами, и собственно самой стратегии развития города. Сегодня город определяет приоритеты и цели развития в новых условиях, и переговоры с крупными девелоперами ведутся с опорой на эти цели. В результате взаимодействие стало более осмысленным и взаимовыгодным.

Реформа при этом предусматривает определенную гибкость в принятии решений Городским советом: его позиция должна оставаться сильной, но с возможностью скорректировать планы под воздействием других точек зрения. Ведь бенефициаром городского развития является как частный, так и публичный сектор. В этом смысле готовность каждой из сторон к открытому диалогу становится ключевой.

Опыт Белфаста особенно важен на фоне изменений российского градостроительного законодательства не в пользу местного самоуправления.

Ключевые слова: Северная Ирландия; местное самоуправление; департамент планирования; городское развитие; Белфаст; реформа; городской совет; принятие решений

Цитирование: Калке С. (2018) Кто лучше знает, каким должен быть город? Реформа местного самоуправления 2015 г. в Северной Ирландии // Городские исследования и практики. Т. 3. № 1. С. 78-87. DOI: https://doi. org/10.17323/usp31201878-87

1 Сапунова Марина Викторовна, градостроитель, Высшая школа урбанистики имени А.А. Высоковского ФГРР НИУ ВШЭ; Российская Федерация, 101000, Москва, ул. Мясницкая, д. 13 стр. 4; E-mail: msapunova@hse.ru 